\title{
PARTAI POLITIK ISLAM DI LEMBAGA LEGISLATIF KOTA MAKASSAR
}

\section{ISLAMIC POLITICAL PARTIES IN THE LEGISLATIVE INSTITUTION OF MAKASSAR CITY}

\author{
Muhammad Nur \\ Balai Penelitian dan Pengembangan Agama Makassar \\ Jl. AP. Pettarani No.72 Makassar \\ Email: mnur4962@gmail.com
}

Naskah diterima tanggal 3 Oktober 2016. Naskah direvisi tanggal 24 Oktober 2016. Naskah disetujui tanggal 9 November 2016.

\begin{abstract}
Abstrak
Di Kota Makassar partai politik Islam hingga saat ini belum terlihat keseriusanya dalam menjalankan fungsinya sebagai wadah penyambung aspirasi antara masyarakat dan legislatif. Masyarakat belum merasakan langsung adanya perubahan yang lebih baik yang dilakukan secara nyata oleh partai politik Islam. Berdasarkan realitas tersebut maka pokok masalah yang dibahas dalam penelitian ini adalah bagaimana peran partai politik Islam dalam mensejahteraan masyarakat di Kota Makassar. Penelitian ini bertujuan untuk mendeskripsikan kondisi obyektif tentang bagaimana peran pertai politik Islam di legislatif dan bagaimana proses terciptanya kesejahteraan masyarakat. Masalah di atas di analisis dengan menggunakan metode deskriptif kualitatif dengan pendekatan fenomenologi. Analisis dilakukan dan diawali dengan pengumpulan data yang diperoleh melalui wawancara mendalam dengan sejumlah informan kunci yang ditetapkan dengan menggunakan sampel purposive yang sifatnya dapat memberikan informasi secara utuh dan mengetahui permasalahan dari objek penelitian. Berdasarkan hasil penelitian ini partai politik Islam di rekomendasikan untuk konsisten turun kebawah untuk mendengar langsung aspirasi masyarakat. Selain itu, juga diharapkan untuk mengedepankan kerja nyata yang bisa dirasakan langsung manfaatnya oleh masyarakat.
\end{abstract}

Kata Kunci: partai politik, lembaga legislatif, kesejahtaraan, Makassar.

\begin{abstract}
Islamic political party in Makassar city, so far has not seen in its function as a mediator between the aspirations of the public and the legislature. The Public of Makassar has yet to feel the direct changes to be better performed significantly by Islamic political parties. Based on the reality of the subject matter discussed in this study is how the role of Islamic political parties to increasingly wealth of public in Makassar. Above that problem was analyzed using descriptive qualitative method with phenomenological approach. The analysis was conducted and begins with the collection of the data obtained through interviews with a number of key informants were determined using purposive sampling that are able to provide full information and know the problems of the research object. The results of this study found, people have not felt any significant role of Islamic political parties in Makassar. Based on these results an Islamic political party recommended for consistently coming down to listen directly to people's aspirations. In addition, it is also expected to put forward the real work that can be felt directly by society.
\end{abstract}

Keywords: political party, legislative institution, wealth, public.

\section{PENDAHULUAN}

$\mathrm{P}$ artai politik Islam di Indonesia merupakan suatu aplikasi adanya relasi antara Islam dan politik yang dalam spektrum sejarahnya seringkali mengalami jalan buntu, baik pada masa pemerintahan Presiden Soekarno ataupun pada masa pemerintahan Presiden Soeharto. Partai politik Islam sebagai pesaing kekuasaan yang potensial, dapat meruntuhkan landasan negara yang nasionalisme. Sementara itu, para aktivis politik Islam memandang bahwa negara telah melakukan manuver untuk menghilangkan arti penting politik Islam dan pada saat yang sama mendukung gagasan mengenai masyarakat politik yang sekuler (Effendy, 1998: 4). 
Menyimak perjalanan sejarah hubungan antara politik dan Islam yang menyudutkan peran penting politik Islam dalam sebuah negara, melahirkan evolusi pemikiran baru terhadap lahirnya paradigma baru dalam aktivis politik Islam yang memuncak dan mengambil peran strategisnya ketika reformasi digulirkan. melainkan telah mendefenisikan kembali cita-cita politik Islam yang berpijak pada menyeru kebaikan dan mencegah kemungkaran pada cita utama dalam praktik sosial politik yang terbingkai dalam konsep yang sering disebut masyarakat madani (Effendy, 1998: 4).

Perwujudan transformasi pendekatan politik dalam bentuk partai politik Islam saat ini, nampak pada partai-partai Islam yang mencoba mewujudkan cita ideal politik Islam dengan ikut serta dalam sistem politik di Indonesia. Maka partai-partai Islam tersebut mengemas dirinya dalam bentuk ideologi kepartaian tertentu, yang semua itu bertujuan agar dapat menarik minat dan simpatisan bagi calon pendukung mereka dengan satu tujuan yang sama (Effendy, 1998: 25).

Perspektif apapun wujud suatu partai yang lahir dan dapat ikut serta dalam pemilu, negara memberikan jaminan ketentuan sebagaimana termuat dalam Pasal 6 Undang-Undang No. 31 Tahun 2002 Tentang Pertai Politik, yang mengisyaratkan hakekat kesamaan dan kesatuan tujuan yaitu peningkatan kesejahteraan masyarakat. UndangUndang partai politik dibuat tidaklah mulukmuluk, mengingat sebahagian besar penduduk Indonesia merupakan bahagian dari peserta pemilu masih hidup di bawah garis kemiskinan, sehingga diharapkan dengan kehadiran partai-parai politik baik itu partai politik yang berbasis ideologi Islam atau partai politik yang berbasis nasionalis dapat menjadi jawaban atas aspirasi masyarakat yang tidak hanya menuntut peningkatan kesejahteraan tapi juga dapat menyuarakan aspirasi serta kebutuhan mereka melalui kebijakan-kebijakan pemerintah (Klingemenn dan Budge Ian, 2004: 28).

Pembicaraan tentang peran politik Islam terutama di negara Muslim seperti Indonesia ibarat menyusuri jalan tanpa ujung. Dengan keberagaman kategori keberislaman penduduk Muslim di Indonesia, baik secara sosiologis, kultural, maupun teologis (Amin, 2003: 1). Kajian-kajian tersebut menyoroti peran-peran politis yang dimainkan oleh kekuasaan-kekusaan maupun organisasi kemasyarakatan non-politik namun memiliki suara resmi dalam sebuah institusi partai politik. Salah satu pertanyaan penting yang selalu mengusik para peneliti mengenai Islam Indonesia adalah mengapa proses Islamisasi yang begitu massif di masyarakat tidak berbanding lurus dengan proses Islamisasi di ranah politik. Pada kenyataanya partai-partai Islam justru semakin tidak laku dalam proses perpolitik di Indonesia. Teori tentang perubahan kecenderungan dari Islam politik ke Islam populer telah menjawab hal ini. Artinya, Islam memang mengalami pertumbuhan yang pesat di masyarakat, namun bukan sebagai ideologi malainkan sebagai bagian dari pop culture yang diciptakan oleh kapitelisme moderen. Islam ideologis bukanya tidak tumbuh, namun mereka tidak pernah menjadi arus utama dari percaturan politik Indonesia (Amin, 2003: 7).

Pemikiran ini menuntut adanya bentuk baru penafsiran yang lebih terbuka dan kreatif terhadap sesuatu doktrian agama terkait dengan dimensi-dimensi sosial politik. Dalam praktek politik di hampir negara-negara moderen saat ini, baik yang bercorak demokratis maupun totaliter, kehadiran partai politik tidak dapat dielakkan. Di negara-negara demokratis, partai pilitik dipakai sebagai sarana untuk mewujudkan hak rakyat dalam menentukan figur-figur yang akan menjadi pemimpinya. Sedangkan di negara-negara totaliter, partai didirikan oleh elit politik dengan pertimbangan bahwa rakyat perlu dibina agar tercipta stabilitas yang berkelanjutan (Budjiardjo, 1982: 159).

Tidakmengherankanjikaperebutan kekuasaan politik mewarnai sejarah umat Islam, tidak hanya diantara dinasti-dinasti yang bersaing tetapi juga dalam lingungan dinasti yang memerintah. Umat Islam telah melihat dalam sejarah mereka beberapa dinasti pemerintahan yang besar tetapi tidak luput dari pergolakan dan perebutan kekuasaan politik (Salim, 2002: 2).

Meski tidak ada konsep yang baku tentang bagaimana bentuk kepemimpinan dan proses suksesi kepemimpinan di masyarakat muslim, namun dalam Alquran dan Hadis telah banyak sekali disebutkan prinsip-prinsip yang harus dijalankan oleh setiap pemimpin muslim. Sehingga jika dijelaskan secara sistematis akan bisa menunjukkan bentuk kepemimpinan dalam Islam (Madany, 2010: 5).

Selain itu yang menjadi tujuan utama dari partai politik Islam dalam realitas sulit untuk dilaksanakan, bahkan cenderung hanya dijadikan jargon bagi partai politik Islam dan 
individu yang diusungnya untuk mendulang suara demi tercapainya tujuan partai secara pragmatis yakni menempatkan wakil-wakilnya sebagai pemenang pemilu atau lolos sebagai anggota legislatif, persoalan apakah dapat mewujudkan kesejahteraan bagi masyarakat adalah urusan kedua, sehingga masyarakat cenderung merasa kehadiran partai politik Islam belum dapat memberikan kontribusi secara langsung bagi peningkatan kesejahteraan masyarakat (Madany, 2010: 9).

Pelaksanaan pemilihan umum dan partai politik dilihat dari sudut pandang politik merupakan suatu perwujudan dari demokrasi di mana masyarakat adalah penentu dalam menentukan wakilnya dalam melaksanakan roda pemerintahan baik yang duduk dalam badan legislatif maupun badan eksekulif dimana harapan masyarakat terhadap wakilnya dapat mempasilitasi kepentingan masyarakat yang memilihnya (Budiardjo, 1982: 18).

Dalam pelaksanaan model pemilihan langsung oleh masyarakat tersebut sebagai sebuah legitimasi dari seseorang untuk menduduki jabatan selaku anggota legislatif maupun eksekutif, maka ditetapkanlah tahapan-tahapan yang dinamakan kampanye atau suatu cara untuk mengenalkan kepada publik atau masyarakat terhadap partai maupun selaku pribadi yang diusung oleh sebuah partai. Tahapan masa kampanye dimulai dengan suatu cara yang dilakukan oleh para kandidat ataupun partai pengusungnya untuk menjalankan apa yang disebut "jual kecap" atau dengan kata lain yaitu suatu usaha-usaha yang tersistematis dan terstruktur untuk berusaha mempengaruhi masyarakat melalui janji-janji yang dikemas dalam bahasa yang rapi yaitu visi dan misi sebuah partai ataupun kandidat yang diusungnya. Oleh karana itu, amat penting untuk dikaji dalam suatu analisis deskriptif kualitatif terhadap eksistensi Partai Politik Islam dalam mensejahteraan masyarakatnya (Budiardjo, 1982: 20).

Berdasarkan uraian diatas, dan untuk memfokuskan ruang lingkup pembahasan dalam tulisan ini, maka yang menjadi pokok masalah dalam penelitian ini adalah bagaimana peran partai politik Islam dalam mensejahterakan masyarakat di Kota Makassar.

\section{Tinjauan Pustaka}

\section{Islam dan Politik}

Islam dan politik memiliki hubunga yang erat dalam bentuk relasi secara fungsional. Dalam bentuk hubungan yang demikian, Islam berfungsi sebagai salah satu aspek yang penting dalam kehidupan sosial umat manusia. Sebagai doktrin, Islam memperkenalkan beberapa konsep yang berhubungan dengan politik. Konsep pemimpin. Misalnya, dapat dipahami bahwa dalam suatu masyarakat dapat diperlukan suatu pemerintahan. Begitu juga dengan kata musyawarah, yang awalnya berbentuk konsep musyawarah merupakan salah satu bentuk pengambilan keputusan yang demokratis. Interpretasi politis dan implementasi dari doktrin-doktrin semacam ini menyababkan Islam dipahami sebagai suatu simbol politik dan ideologi politik (Putuhena, 2007: 257).

Jika politik dipandang sebagai kekuasaan maka kehidupan politik dapat diklasifikasikan dalam tiga hal pokok, yaitu pertama sebagai sumber kakuasaan kedua sabai distribusai kekuasaan dan ketiga sebagai pelaksanaan kekuasaan (Sho'ub, 1997, 153).

Islam mengakui tiga macam sumber kekuasaan, yaitu Allah swt, masyarakat, dan perorangan (individu). Sedangkan mengenai distribusi kekuasaan dan pelaksanaan kekuasaan, hal itu merupakan rekayasa manusia. Berkenaan dengai itu Islam mempunyai beberapa konsep etika yang perlu diperhatikan seperti, keadilan, kajujuran, dan keterbukaan. Jadi selain berfungsi sebagai ideologi politik, Islam juga berfungsi sebagai etika politi (Sho'ub, 1997: 158).

Islam dan politik mempunyai titik singgung erat, bila keduanya dipahami sebagai sarana untuk menata kebutuhan hidupan manusia secara menyeluruh, Islam tidak hanya dijadikan kedok untuk mencapai kepercayaan dan pengaruh dari masyarakat semata. Politik juga tidak hanya dipahami sekedar sebagai sarana menduduki posisi dan otoritas formal dalam struktur kekuasaan. Politik yang sekedar dipahami sebagai perjuangan mencapai kekuasaan atau pemerintahan, hanya akan mengaburkan tujuanya secara luas dan menutup konstribusi Islam terhadap politik secara umum. Sering dilupakan bahwa Islam dapat menjadi sumber inspirasi kultural dan politik, pemahaman terhadap term politik secara luas akan memperjelas korelasinya dengan Islam (Mahfudh, 2007, 202). 
Dalam konteks Indonesia, korelasi Islam dan politik juga menjadi jelas dalam penerimaan pancasila sebagai satu-satunya asas. Ini bukan berarti manghapus cita-cita Islam dan melenyapkan unsur Islam dalam peraturan politik di tanah air. Sejauh mana nilai Islam mampu memberikan inspirasi dalam percaturan politik, bergantung pada sejauh mana kalangan muslimin mampu pampil dangan gaya baru yang dapat mangembangkan kekayaan pengetahuan sosial dan politik untuk memetakan dan menganalisis transformasi sosial yang ada (Mahfudh, 2007: 202).

Dalam ajaran Islam, pemenuhan keadilan dan kesejahteraan merupakan keharusan bagi suatu pemerintah yang tak perlu berlabal Islam yang didukung oleh masyarakat. Rasullah sendiri sebenarnya mamberikan isyarat, bahwa kekuasaan memang bukan tujuan dari politik kaum muslimin. Rasulullah sendiri mencanangkan usaha perbaikan budaya politik atau pelurusan pengelolaan kekuasaan dan menghimpun kaum muslimin terutama ulama dan para elit politiknya untuk menjadi moralis politik (Syahrur, 2003: 193).

Peran ini sangat bergantung pada ketulusan pandangan para elit Islam sendiri, kedalaman memahami Islam secara utuh, sekaligus keluasan cakrawala orang diluar kekuasaan politik Islam untuk melihat potensi dan kekuasaan moral Islam, dalam mengarahkan proses kehidupan bangsa guna mencapai keadilan dan kesejahteraan yang dicitacitakan. Memang upaya ini tidak begitu mudah, karena masih cukup banyak kendala di kalangan kaum muslim sendiri (Sahrur, 2003: 193).

Konsekuensinya, Islam harus selalu mampu berdialog dengan peradaban apapun, kapanpun dan di manapun. Islam dapat dikatakan sebagai agama yang membuka dirinya bagi perubahan-perubahan malalui ijtihad. Inilah salah satu keistimewaan Islam baik sabagai agama maupun sebagai fenomena sosial dan politik, baik secara historis maupun secara soilogis (Abdullah, 2011: 127).

Sejarah telah mencatat bahwa salah satu karekteristik agama Islam pada masa awal kepemimpinanya, ialah kejayaan di bidang politik. Penuturan sejarah Islam di penuhi oleh kisah kejayaan sejak Nabi Muhammad saw sendiri (periode Madinah) sampai masa-masa jauh sesudah beliau wafat, terjalin dengan kejayaan di bidang politik itu dibarengi juga dengan kejayaan di bawah pimpinan para sehabat nabi. Dari konteks politik, Islam juga nampaknya tidak bisa mengelak dari perubahan- perubahan itu. Munculnya Islam sebagai suatu ideologi misalnya, sesungguhnya tidak terlepas dari tuntunan politis dan sosio kultural dalam kondisi kesejarahan tertentu. Perjalanan sejarah Islam menunjukan bahwa tantangan yang berbede telah menghasilkan respon yang berbeda pula, dari sini bisa diasumsikan bahwa suatu ekspresi politis dari umat Islam tidak akan tetap sama jika mereka dihadapkan pada kondisi sosial politik yang berbeda (Jufri, 1989: 121).

Selanjuatnya dengan melihat sepintas negaranegara yang saat ini dikanal sebagai negara Islam, dapat dikemukakan bahwa adanya variasi dalam konsep Islam sebagai dasar negara. Saudi Arabia misalnya adalah sebuah kerajaan Islam yang diperintah dengan sistem monarkhi yang turun temurun. Libya diproklamirkan oleh Kolonel Khadafi sebagai sebuah negara sosialis Islam. Iran dinyatakan sebagai Republik Islam yang mencoba menerapkan sistem demokrasi parlementer ala Barat (Pranowo, 1992: 6).

Beberapa contoh variasi di atas sebagian dapat dihubungkan dengan kenyataan tidak pernah adanya konsensus di antara para ulama dalam interpretasi mereka atas ajaran maupun sejarah Islam yang digunakan sebagai dasar dalam membangun suatu sistem Islam. Sekalipun begitu, Alquran memberikan petunjuk berupa prinsip-prinsip dasar yang bersifat umum tentang sitem pemerintahan. Dalam soal ketatanagaraan dan pemerintahan, ada sejumlah ayat yang bisa dianggap sebagai prinsipprinsip tersebut, antara lain: prinsip musyawarah (syura), keadilan, prikemanusiaan, persamaan, kebebasan beragama, dan persatuan (Mudhorif, 2011: 131).

\section{METODE PENELITIAN}

Sampel yang digunakan dalam penelitian ini adalah sampel porpusif yang sifatnya dapat memberikan informasi secara utuh dan mengetahui betul permasalahan dari objek penelitian. maka, dalam penelitian ini ditentukan bahwa sampel merupakan elemen penting dari populasi target, di mana populasi target adalah ketiga parpol Islam tersebut yang eksis di Kota Makassar (Sugiyono, 2009 dan Arikunto, 2006).

Penelitian ini menggunakan data primer yang bersumber dari hasil wawancara (interview) dengan pihak-pihak yang dianggap memahami masalah yang diteliti, data yang diperoleh dari lokasi penelitian berupa observasi, wawancara, dan 
dokumentasilangsung di analisis dengan mengamati bagaimana proses perkembangan Partai Politik Islam di Kota Makassar. maka sumber datanya adalah Partai Politik Islam dan masyarakat terpilih dalam hal ini adalah organisasi kemasyarakatan, sedangkan objek penelitianya berupa bagaimana peran partai politik Islam dalam mawujudkan kesejahteraan masyarakat di Kota Makassar

Yang menjadi sumber data dalam penelitian ini adalah PKS, PPP, PBB, NU, Muhammadiyah, Wahdah Islamiyah dan Ijabi (masing-masing ketua dan sekretaris). Penelitian ini dilakukan pada tahun 2012

\section{PEMBAHASAN}

Kota Makassar Ibu Kota Provinsi Sulawesi Selatan dalam basis dinamika perputaran modal dalam pasar ekonomi dan mainstream politik Kota Makassar merupakan sentral kekuasaan politik dan kekuasaan ekonomi sehingga diklaim oleh beberapa pemangku kekuasaan birokrasi pemerintahan sebagai Pintu Gerbang Kawasan Timur Indonesia.

Populasi penduduk Kota Makassar mayoritas berpendidikan SLTP, SLTA dan untuk Pendidikan Tingkat Diploma dan Sarjana tidak dalam skala mayoritas meskipun banyak yang melanjutkan studi ke pendidikan tinggi, kepercayaan religius sebagian besar menganut Agama Islam (NU, Muhamadiyah, Jamảah Tabliq, Wahdah Islamiyah, Hizbut Thahrir, Ijabi), Katolik dan Kristen Protestan serta Kristen Pentaikosta merupkan kekuatan nomor 2 setelah Islam selain itu terdapat juga Budha dan Khonghuchu serta Hindu, suku terbesar di Kota Makassar adalah Bugis dan Makassar, terdapat juga etnis lokal yaitu Toraja, Mandar, Luwu serta etnis pendatang seperti Bali, Jawa, Tionghoa yang sudah mendiami ratusan tahun serta etnis lain. Mata pencarian penduduk Kota Makassar sebagian besar beraktifitas pada struktur pemerintahan pejabat negara, pegawai negeri sipil, pegawai swasta, buruh, badan usaha milik negara, nelayan, guru, tentara nasional Indonesia, kepolisian, pedagang dan lain lain.

\section{Peran Partai Politik Islam dalam Mensejahterakan Masyarakat}

Berkaitan dengan kesejahteraan sosial masyarakat dengan peran partai politik Islam dalam memperjuangkan peningkatan kesejahteraan masyarakat kota Makassar di letakan melalui program kesejahteraan dalam perjuangan partai. Pandangan tersebut didasarkan pada hasil wawancara dengan Busranuddin Baso Tika, ketua umum DPD Partai Persatuan Pembangunan (PPP) Kota Makassar.

Program kesejahteraan masyarakat sebagian yang dikemukakan beberapa partai politik tersebut diarahkan pada peningkatan sarana prasaranan pelayanan umum seperti pendidikan, kesehatan, dan jaminan sosial yang adil dan merata serta menjangkau seluruh lapisan masyarakat tanpa terkecuali. Pandangan berikut ini merupakan ciri peningkatan kualitas manusia Indonesia. Manusia yang berkualitas itu adalah manusia yang mempunyai pengetahuan dan keterampilan yang memadai serta memiliki kualitas kesehatan yang baik (Busranuddin Baso Tika, wawancara di Makassar, 19/10/2012). Dari sinilah PPP Kota Makassar berusaha memperlihatkan peranya dalam meningkatkan kesejahteraan masyarakat.

Perjuangan PPP tersebut agar program pada peningkatan usaha serta pengembangan kemampuan dan kemandirian peranan lembaga swadaya masyarakat (LSM) serta organsiasi kemasyarakatan dan keagamaan yang bergerak di bidang sosial, pendidikan, dan kesehatan. Selain itu, perjuangan PPP juga untuk menciptakan peningkatan kemampuan dan peran serta pemerintah dalam meningkatkan taraf kehidupan masyarakat melalui program peningkatan kualiats pelayanan pendidikan, kesehatan, dan jaminan sosial. Di bidang ekonomi juga memperjuangkan agar pemerintah selaku pelaksana kebijakan agar membuka seluas-luasnya ruang ekonomi mandiri bagi masyarakat dan selain itu juga dengan menciptakan banyak lapangan kerja guna mengatasi pengangguran dan peningkatan taraf hidup yang layak bagi masyarakat kota Makassar. (Busranuddin Baso Tika, Wawancara di Makassar, 19/10/2012).

Mengenai peningkatan kesejahteraan masyarakat di bidang ekonomi, PPP menjadikanya salah satu program partai, bahwa setiap masyarakat berhak mendapatkan pekerjaan dan penghidupan yang layak. Dan ini sesuai dengan amanah pasal 27 ayat 1 UUD 1945. Program tersebut diarahkan pada pematangan strategi pemenuhan kebutuhan dasar dan penciptaan lapangan kerja dan dunia usaha. Apa yang diperjuangkan PPP tersebut menjadi acuan bagi pembangunan pemerintah kota 
Makassar untuk memprioritaskan pengentasan kemiskinan, penghapusan pengangguran, dan kesenjangan sosial ekonomi. Dalam konteks ini PPP selalu mendesak pemerintah agar hal tersebut menajdi sasaran utama pembangunan kota, yaitu pembangunan lebih menekankan pada pembangunan sumber daya manusia. Apa yang disebutkan terakhir ini, yakni sumber daya manusia (SDM). Merupakan hal yang penting dan mendasar karena pembangunan sumber daya manusia yang dimaksud adalah pembangunan manusia Indonesia yang berakhlak yakni beriman dan bertakwa kepada Allah swt, berilmu, cerdas, sehat, kritis, dan kreatif, berpola hidup sederhana, sanggup bekerja keras, hemat, jujur, efisien, mandiri, dan penuh pengabdian sehingga tercapai kesejahteraan yang merata di seluruh masyarakat. Pada pembangunan SDM inilah, PPP selalu berkomitmen baik sebagai mitra maupun kontrol pemerintah. ( $\mathrm{H}$. Arifuddin Lewa, wawancara di Makassar, 22/10/2012).

Sedangkan peningktan kesejahteraan di bidang pendidikan, PPP senantiasa berusaha agar program wajib belajar 9 tahun dapat dilaksanakan secara tuntas di Makassar sesuai dengan amanah UUD 1945 pasal 31. Peningkatan kualiats pendidikan juga dengan meperjuangkan terwujudnya kesejahteraan para tenaga pendidik di setiap jenjang pendidikan. Selain itu dengan mendorong pemerintah kota agar meningkatkan kualiats sarana dan prasarana pendidikan yang layak agar tercapai target dan tujuan pendidikan yang diharapkan. (H. Arifuddin Lewa, wawancara di Makassar, 22/10/2012).

Sebagai partai yang berideologi Islam, peningktan kesejahteraan masyarakat dibidang mental spiritual, PPP memperjuangkan agar pemerintah kota Makassar juga memperhatikan aspek mental dan spiritual, karena dengan mental dan spiritual yang baik, maka akan terwujud tatanan masyarakat yang baik. Perjuangan dalam peningkatan kesejahteraan mental spiritual ini ditandai dengan terbitnya perda yang berkenaan dengan hal tersebut, serta mendesak pemerintah kota Makassar untuk memperhatikan signifikansi pembangunan mental spiritual masyarakatnya.

Di legislatif (DPRD Kota Makassar) fraksi PPP melalui wakil-wakilnya senantiasa berjuang untuk menerbitkan peraturan daerah (perda) yang terkait langsung dengan peningkatan kesejahteraan masyarakat. Ada beberapa perda yang telah dihasilkan dan di mana fraksi PPP terlibat aktif di dalamnya. Di antaranya Perda Nomor 1 Tahun 2012 Tentang Pendidikan Baca Tulis Alquran dan Perda Nomor 7 Tahun 2006 Tentang Pengawasan, Pengendalian, dan Penjualan, serta Perizinan Minuman Beralkohol di Kota Makassar. Kedua perda inilah yang dianggap sebagai hasil perjuangan fraksi PPP di DPRD. Harus diakui, hasil dari perjuangan PPP terhadap peningkatan kesejahteraan masyarakat di kota Makassar melalui perda-perda tentu saja amsih jauh dari yang diharapkan, khususnya terkait dengan peningkatan kesejahteraan di bidang pendidikan, kesehatan, dan ekonomi. Hal ini diakui karena minimnya jumlah anggota PPP di legislatif, sehingga dalam memperjuangkan agenda partai terkait kesejahteraan masyarakat sangat sulit karena kurangnya dukungan dari masyarakat. (H. Arifuddin Lewa, wawancara di Makassar, 22/10/2012).

Terkait dengan Perda Nomor 1 Tahun 2012 terkait Baca Tulis Alquran, PPP memperjuangkan peran serta pemerintah dalam menyukseskan program pengentasan buta aksara Alquran. Hal ini terlihat dalam Bab VIII pasal 14 perda tersebut yang menyatakan bahwa pelaksanaan pendidikan baca tulis Alquran merupakan tanggung jawab bersama antara pemerintah dan amsyarakat. Pemerintah kota bertanggung jawab meneydiakan anggaran pendidikan baca tulis Alquran sebagai bagian dari anggaran pendidikan nasional. Penyediaan anggaran pendidikan baca tulis Alquran ditetapkan dalam anggaran pendapatan dan belanja daerah (APBD). Selain itu, kelanjutan tentang pendanaan penyelenggaraan pendidikan baca tulis Alquran lebih lanjut diatur melalui surat keputusan walikota.

PPP memperjuangkan pengawasan penyelenggaraan pendidikan baca tulis Alquran diperankan juga oleh pemerintah dalam hal ini dinas pendidikan dan kementerian agama. Hal ini tertuang dalam pasal 15 Bab IX perda tersebut. Penyelenggaraan pendidikan baca tulsi Alquran juga dilaksanakan pada semua jalur pendidikan dengan melibatkan sekolah dan diawasi oleh komite sekoah. Pengawasan program tersebut dilaksanakan dengan prinsip transparansi dan akuntabilitas publik 
(Busranuddin Baso Tika, wawancara di Makassar, 19/10/2012).

Perda tersebut juga memuat sanksi bagi lembaga terkait yang melanggar amanah perda tersebut. Dalam Bab XI Pasal 17 diatur mekanisme sanksi bagi lembaga yang melanggar mulai dari sanksi berupa teguran lisan, surat teguran tertulis, pembatasan kegiatan, penutupan kegiatan, dan pencabutan izin kegiatan.

Perda selanjutnya yang juga terbit berkat perjuangan fraksi PPP di DPRD Kota Makassar adalah Perda Nomor 7 tahun 2006 tentang Pengawasan, pengendalian, dan penjualan, serta Perizinan Minuman Beralkohol di Kota Makassar. Melalui perda tersebut, peran serta peemrintah kota terlibat aktif dalam hal pengawasan dan aktif dalam memberikan laporan hasil pelaksanaan pengendalian kepada aparat terkait.

Target yang ingin dicapai oleh PPP melalui perda ini adalah dengan memeprketat penjualan minuman keras agar penjualannya tidak dilakukan dengan bebas serta mempunyai izin operasional dari pemerintah Kota Makassar. Gunanya adalah untuk mempersempit penjualan minuman keras agar masyarakat menjadi lebih aman dan potensi kerawanan sosial yang diakibatkan oleh minuman keras dapat diminimalisir (Busranuddin Baso Tika, wawancara di Makassar, 19/10/2012).

Selain kedua perda tersebut, perjuangan fraksi PPP di legislatif, menurut Burhanuddin Baso Tikka (Ketua Umum DPC PPP Kota Makassar) adalah mendukung dan mengawasi program pendidikan dan kesehatan gratis. Meskipun program tersebut adalah program pemerintah provinsi Sulawesi Selatan, namun, PPP merasa memiliki tanggung jawab untuk berperan serta dalam mensukseskan program tersebut, karena program tersebut berkenaan langsung dengan pelayanan sosial masyarakat yang akhirnya adalah meningkatkan taraf kesejahteraan sosial masyarakat, khususnya di Kota Makassar. (Busranuddin Baso Tika, wawancara di Makassar, 19/10/2012).

Perjuangan dan pandangan PPP Kota Makassar tersebut sejalan dengan partai keadilan sejahtera (PKS). PKS dalam mewujudkan kesejahteraan masyarakat ditekankan sebagai program aturan partai, di bidang peningkatan kesejahteraan masyarakat, PKS dalam jangka panjang cenderung sifatnya seragam dari pusat ke wilayah hingga daerah (kabupaten/kota). Namun, ada pula program kerja yang sifatnya menyesuaikan dengan kondisi setempat di mana ia berada. Misalnya, mengangkat isu-isu budaya lokal yang sifatnya khas atau disesuaikan dengan program pemerintah setempat seperti ikut mensukseskan terlaksananya program pemrintah Sulawesi Selatan terkait pendidikan dan kesehatan gratis. Menurut Hasan Hamido (ketua umum DPD PKS Kota Makassar, bahwa tidak ada alasan bagi PKS untuk tidak ikut serta mensukseskan program pendidikan dan kesehatan gratis tersebut (Hasan Hamido, wawancara di Makassar, 24/10/2012).

Menurut Hasan Hamido, dalam pandangan PKS, ada tiga unsur penunjang kesejahteraan, jika tiga unsur tersebut terpenuhi maka kesejahteraan masyarakat akan tercapai. Ketiga unsur tersebut adalah spiritual, cara pandang atau pola pikir, dan kesehatan jasmani. Yang utama dari ketiga unsur tersebut adalah kematangan spiritual yang mencerahkan masyarakat. Sejahtera dalam hal ini bukan hanya bersifat materil semata, namun kesejahteran yang dimaksud adalah bersifat mental spiritual (Hasan Hamido, wawancara di Makassar, 2012).

Terkait dengan pembangunan kesejahteraan masyarakat dibidang spiritual, fraksi PKS di DPRD kota Makassar juga turut andil dalam penyusunan dan pengesahan Perda Nomor 1 Tahun 2012 Tentang Baca Tulis Alquran dan Perda Nomor 7 Tahun 2006 Tentang Minuman Beralkohol. Fraksi PKS memperjuangkan pembatasan penjualan miras hanya di tempat-tempat tertentu serta pengurangan kadar alkohol miras. Selain itu juga fraksi PKS menegaskan sikap untuk menutup dan mencabut izin operasional bagi tempat-tempat yang melanggar ketentuan perda tersebut (Muhammad Iqbal Jalil, wawancara di Makassar, 24/10/2012).

Demikian pula dengan Perda Nomor 1 Tahun 2012 Tentang Baca Tulis Alquran, fraksi PKS memperjuangkan agar setiap lembaga pendidikan formal di setiap jenjang memprogramkan wajib baca tulsi Alquran bagi siswanya yang beragama Islam. Terkait pengawasan terhadap pelaksanaan program tersebut, fraksi PKS dan DPC PKS kota Makassar juga terlibat aktif dalam melakukan kontrol sesuai dengan mekanisme yang ditetapkan dan tidak segan-segan untuk mendukung pemberian sanksi bagi lembaga terkait yang tidak mengindahkan perda tersebut. Fraksi PKS juga senantiasa mendesak kepada walikota dan jajaran pemerintahan terkait 
untuk memperhatikan ketersediaan anggaran guna mensukseskan program pemberantasan buta aksara Alquran di Kota Makassar (Muhammad Iqbal Jalil, wawancara di Makassar, 24/10/2012).

Terkait dengan peningkatan kesejahteraan di bidang ekonomi, fraksi PKS sangat memperhatikan eksistensi pasar tardisional di Kota Makassar yang sedikit demi sedikit mulai tergeser dan tergusur oleh maraknya pembangunan mall dan pasar swalayan di Kota Makassar. Untuk itu, fraksi PKS merasa berkewajiban untuk memperjuangkan nasib pasar tradisional di Kota Makassar. Dalam pandangan PKS, pasar tradisional merupakan membangun dan mengembangkan perekonomian bagi usaha kecil dan sektor informal sebagai salah satu pilar penting perekonomian daerah yang dibangun atas asas kekeluargaan. Hilangnya pasar tardisional dengan sendirinya akan mematikan sektor-sektor ekonomi masyarakat kelas bawah di Kota Makassar. Dengan demikian, pasar tradisional harus dijaga dan dikembangkan agar bisa berkontribusi bagi peningkatan kesejahteraan sosial ekonomi masyarakat dan mampu bersinergi dalam membangun perekonomian Kota Makassar (Mudzakkir Ali Djabir, wawancara di Makassar, 1/11/2012).

Terkait dengan hal tersebut, fraksi PKS DPRD Kota Makassar terlibat aktif dalam menyusun dan memperjuangkan terbitnya peraturan daerah tentang pasar tradisional dan hasilnya terbit Perda Nomor 15 Tahun 2009 Tentang Perlindungan, Pemberdayaan Pasar Tradisional dan Penataan Pasar Modern di Kota Makassar. Fraksi PKS memperjuangkan egalitarianisme hak antara pasar tardisional dan pasar modern dalam bidang ekonomi di Kota Makassar. Untuk itu penyelenggaran perlindungan pasar tradisional dan penataan pasar modern di Kota Makassar dilaksanakan dengan asas kemanusiaan, keadilan, kesamaan kedudukan dan kemitraan, ketertiban dan kepastian hukum, kelestarian lingkungan, serta kejujuran dan persaingan yang sehat. Dengan terbitnya perda tersebut, dapat menjaga eksistensi pasar tradisional di Kota Makassar dan dapat menekan laju pertumbuhan pasar modern yang sangat pesat, sehingga terjadi perimbangan keadilan ekonomi di antara lapisan masyarakat.

Peningkatan kesejahteraan di bidang pendidikan dan kesehatan, fraksi PKS dan DPC PKS terlibat aktif dalam mensukseskan program tersebut baik dalam hal mengawal pelaksanaan program hingga mengawal ketersediaan anggaran guna mensukseskan program tersebut. Bagi PKS pendidikan dan kesehatan graris adalah "harga mati" dan merupakan hak dasar masyarakat yang wajib dipenuhi oleh pemerintah (Mudzakkir Ali Djabir, wawancara di Makassar, 1/11/2012).

Perjuangan dan pandangan PKS Kota Makassar tersebut sejalan dengan partai bulan bintang (PBB). PBB dalam mewujudkan kesejahteraan masyarakat meletakkan sebagai program aturan partai yang mengikut dari pimpinan pusat, wilayah hingga kota/daerah. Perjuangan peningkatan kesejahteraan masyarakat di bidang pendidikan menurut Drs. Rahman, M. Si, dirinya sebagai satu-satunya wakil PBB di DPRD kota Makassar menyatakan bahwa dirinya memperjuangkan terlaksananya program pemenuhan hak pendidikan masyarakat, khususnya program wajib belajar 9 tahun sebagaimana amanah undang-undang. Di komisi D, sebagai wakil PBB memperjuangkan agar Perda Nomor 3 Tahun 2006 Tentang Penyelenggaraan Pendidikan dapat terealisasi sebagaimana mestinya.

Sebagaimana diungkapkan oleh Rahman, dalam perda tersebut mengamanahkan kepada pemerintah untuk menjamin terselenggaranya program wajib belajar dari tingkat SD/MI sampai dengan tingkat pendidikan SMP/MTs. Perda tersebut juga mengamanahkan kepada pemerintah untuk terlibat aktif dalam melakukan pengawasan atas penyelenggaraan pendidikan dalam rangka pembinaan satuan pendidikan. Walikota sebagai pelaksana pemerintahan berwenang untuk mengambil langkah administratif terhadap penyelenggaraan pendidikan. PBB juga aktif melakukan kontrol dalam penganggaran pendidikan agar terpenuhi amanah 20\% anggaran pendidikan dalam Anggaran Pendapatan dan Belanja Daerah (APBD) Kota Makassar setiap tahunnya (Mudzakkir Ali Djabir, wawancara di Makassar, 1/11/2012).

Terkait dengan program pendidikan dan kesehatan gratis, PBB mendukung penuh suksesnya program tersebut. Dalam pandangan PBB pendidikan dan kesehatan gratis adalah kewajiban pemerintah kepada warganya. Oleh karena itu, PBB akan melaksanakan fungsi kontrolnya demi suksesnya program tersebut. Mekanisme pengawasan yang dilakukan oleh PBB berupa kontrol yang ketat hingga level bawah yang bersentuhan langsung dengan masyarakat terkait pelayanan pendidikan dan kesehatan gratis (Rahman, wawancara di Makassar, 16/10/2012). 
Bahwa untuk memenuhi kebutuhan daasar di bidang kesehatan dalam rangka mewujudkan kesehatan umum, maka pemerintah Kota Makassar mengoptimalkan pelayanan kesehatan kepada warga masyarakat kota, hingga peraturan daerah Kotamadya Daerah Tingkat II Ujung Pandang Nomor 15 Tahun 1999 Tentang Retribusi Pelayanan Kesehatan dipandang tidak sesuai lagi dengan kondisi perkembangan kebutuhan masyarakat, hingga perlu ditinjau dan ditetapkan kembali sesuai dengan peraturan perundang-undangan yang berlaku (Rahman, wawancara di Makassar, 16/10/2012).

Terkait dengan pelayanan kesehatan gratis, menurut Rahman, sekalipun program provinsi, namun DPRD kota Makassar telah mengesahkan Peraturan Daerah Nomor 7 Tahun 2009 Tentang Pelayanan Kesehatan di Kota Makassar. PBB memperjuangkan dalam peraturan daerah ini agar pemerintah kota memberikan pelayanan kesehatan kepada masyarakat pada RSUD, puskesmas dan jaringanya, baik penduduk kota maupun penduduk luar kota. Pelayanan kesehatan yang dimaksud dalam peraturan daerah tersebut meliputi, pelayanan kesehatan dasar dan pelayanan kesehatan lanjutan, pelanggaran atas peraturan daerah ini di ancam dengan pidana kurungan paling lama 3 (tiga) bulan atau denda sebanyak banyaknya lima puluh juta rupiah.

\section{PENUTUP}

Peran partai politik Islam dalam meningkatkan kesejahteraan masyarakat di Kota Makassar lebih kepada perjuangan terhadap ranah legislasi dengan merumuskan dan mengsahkan beberapa peraturan daerah terkait peningkatan kesejahteraan masyarakat, baik di bidang material maupun spiritual. Seperti perda baca tulis Alquran, perda tentang miras, perda tentang kesehatan, perda tentang pendidikan, serta perda tentang pesar tradisional dan modern. Diakui sebagai ahsil perjuangan partai politik Islam yang memiliki wakil di DPRD Kota Makassar. Meski demikian, dapat dikatakan peran partai politik Islam dalam peningkatan kesejahteraan masyarakat di Kota Makassar masih belum terlihat secara signifikan, baik berupa produk legislasi terkait kesejahteraan masyarakat, maupun langkah kongkrit di tengah masyarakat. Dapat dikatakan, partai poliik Islam, belum menunjukkan kesungguhan komitmen dan aksi nyata dalam peningkatan kesejahteraan masyarakat di Kota Makassar, setidaknya dia memebrikan pengaruh dalam lahirnya peraturan dan kebijakan yang berpihak pada peningkatan kesejahteraan masyarakat di Kota Makassar.

\section{UCAPAN TERIMA KASIH}

Terima kasih yang sebesar-besarnya peneliti ucapkan kepada berbagai pihak yang telah membantu dalam penelitian ini sehingga artikel ini hadir di hadapan pembaca budiman. Terkhusus kepada para anggota legislatif, tokoh politik, pimpinan wilayah Muhammadiyah, ketua wahdah Islamiyah dang pngurus IJABI, dan infroman lainnya yang saat ini berkiprah di lembaga legislatif di Kota Makassar.

\section{DAFTAR PUSTAKA}

Amin, Zainal Abidin. 2003. Peta Islam Politik PascaSoeharto. Jakarta: Pustaka LP3ES.

Arikunto, Suharsimi. 2006. Prosedur Penelitian: Suatu Pendekatan Praktek. Jakarta. PT Rineke Cipta.

Budjiardjo, Meriam. 1981. Partisipasi dan Partai Politik: Sebuah Bunga Rampai. Jakarta: Gramedia.

Effendy, Bahtiar. 1998. Islam dan Negara: Transformasi Pemikiran dan Praktek Politik Islam di Indonesia. Jakarta: Paramadina.

Jufri, S. H. M. 1989. Dari Saqifah Sampai Imamah. Jakarta: Pustaka Hidayah.

Klingemenn, Richard I Hofferbert; dan Budge Ian. 2004. Pergulatan Partai Pollitk di Indonesia. Jakarta: PT RajaGrafindo Persada.

Madany, Malik. 2010. Politik Berpayung Fiqh: Membedah Perpolitikan Nusantara Dengan Pisau Syariat, Melalui Penggalian Khasanah Islam Klasik Maupun Kontenporer. Yogyakarta: Pustaka Pesantren.

Mahfudh, Sahal. Nuansa Fiqih Sosial. Yogyakarta: LkiS.

Mudhorif, Abdullah. 2011. Masail Al-Fiqhiyyah: Isu-isu Fikih Kontenporer. Yogyakarta: Trans.

Peraturan Daerah Kota Makassar Nomor 1 tahun 2012 tentang Pendidikan Baca Tulis al-Quran.

Peraturan Daerah Kota Makassar Nomor 3 Tahun 2006 tentang Penyelenggaraan Pendidikan di Kota Makassar.

Peraturan daerah Kota Makassar Nomor 7 tahun 2006 tentang Pengawasan, Pengendalian, Pengedaran, dan penjualan, serta Perizinan Tempat Penjualan Minuman Beralkohol.

Peraturan Daerah Nomor 15 Tahun 2009 tentang Perlindungan, pemberdayaan Pasar Tradisional dan Penataan Pasar Modern di Kota Makassar.

Peraturan daerah, Nomor 7 Tahun 2009 tentang pelayanan kesehatan di Kota Makassar.

Pranowo, Bambang. Dinamika Politik Islam di Indonesia, Jurnal Ulumul Quran, Vol III, No. 1, 1992. 
Putuhena, Shaleh. 2007. Histografi Haji Indonesia. Yogyakarta: PT. Lkis.

Salim, Abdul Muin. 2002. Fiqh Siyasah Konsepsi Kekuasaan Politik dalam Al-Quran. Jakarta: PT.Raja Grafindo Persada.

Sho'ub, Hasan. 1997. Islam dan Revolusi Pemikiran.
Surabaya: Risalah Gusti.

Sugiyono. 2009. Metode Penelitian Kuantitatif dan R\&D. Bandung: Alpabeta.

Syahrur, Muhammad. 2003. Tirani Islam:

Geneologi Masyarakat dan Negara. Yogyakarta: LkiS. 